\title{
Histone H3 Lysine 9
}

National Cancer Institute

\section{Source}

National Cancer Institute. Histone H3 Lysine 9. NCI Thesaurus. Code C107429.

The lysine residue found at amino acid position 9 in the histone $\mathrm{H} 3$ protein. Methylation of this residue may be a marker for transcriptionally repressed genes. 